rich deposit. Potato medium yields a pale reddish. brown, glistening, vigorous growth of butyrous consistency. They produce catalase and ammonia, show positive methyl red test and do not produce indol and acetylmethylcarbinol. They are not able to grow in the presence of more than 0.05 per cent phenol.

Only $P$. perolens var. Gdansk, $A$. perolens and $P$. graveolens produce a green, fluorescent, water-soluble pigment, cause green egg-white, grow fairly well at $0^{\circ} \mathrm{C}$, and use acetates as a single source of carbon.

Some other properties are summarized in the accompanying table.

It is proposed to place Achromobacter perolens (strain No. 4430) in the genus Pseudomonas ${ }^{7}$ with the name Pseudomonas perolens because of a single polar flagellum as reported by Turner ${ }^{1}$ and myself ${ }^{4}$ and because of the production of a greenish, fluorescent, water-soluble pigment.

It is hoped to publish a fuller account of this work elsewhere.

My thanks are due to Prof. H. Dam for the hospitality of his laboratory and to Dr. E. Olsen for helpful discussions.

Polytechnical Institute, WACLAW SZYBaLSKI Gdańsk, Poland, and

Department of Biology,

Technical University of Denmark, Copenhagen. Nov. 25.

' Turner, A. W., Austral. J. Exp. Biol., 46, 57 (1927).

a Spanswick, M. P., Amer. J. Pub. Health, 20, 773 (1930).

${ }^{3}$ Levine, M., and Anderson, D. Q., J. Bact., 23, 337 (1932).

Grabiec, S., Szybalski, W., and Tuszyński, W., Bull. Inst. Mar. Trop. Med. Gdańsk (Pöland), 2, No. 3-4, 229 (1949).

s Jensen, L. B., Food Res., 13, 89 (1948).

- Olson, H. C., and Hammer, B. W., Iowa State Coll. J. Sci., 9, 125 (1934).

"Breed, R. S., in Bergey's "Manual of Det. Bacteriology", 82 (Baltimore, 1948).

\section{Temperature Requirements of Penilia avirostris Dana in the Hauraki Gulf, New Zealand}

IN a pilot survey, still in progress, of the plankton of the Hauraki Gulf, Now Zealand, Penilia avirostris Dana was found from December 1948 until April 1949. In December, Penilia was found in small quantities at some stations only; except in one case, the numbers were less than 1 per c.m., and Penilia was only recorded from stations of surface temperature $17 \cdot 8^{\circ} \mathrm{C}$. or above. In January, when apparently extensive multiplication occurred, as many as 1,250 per c.m. were recorded, more usual records being 300-400 per c.m. The modal recorded surface temperature for January was $20^{\circ} \mathrm{C}$. In February, with a modal recorded surface temperature of $20 \cdot 4^{\circ} \mathrm{C}$., the numbers of Penilia declined to 50-150 per c.m., and continued to decline until April, when a sample with less than 1 per c.m. was recorded at a temperature of $18.7^{\circ} \mathrm{C}$. This decline in numbers was reflected in other species. In both January and February, Penilia was frequently the dominant member of the plankton, sometimes forming more than 50 per cent of the planktonic animal population of coastal waters of depth 10-20 fathoms.

Although observations are so far available for one year only, the earlier record of Krämer ${ }^{1}$ that Penilia is a normal member of the summer plankton of the
Hauraki Gulf is apparently confirmed. Occurrence of Penilia in the Gulf is significant because observations made by the Marine Department, New Zealand ${ }^{2}$, over a period of years show that the Hauraki Gulf lies just south of the $17^{\circ} \mathrm{C}$. mean annual isotherm. Temperature observations in the coastal waters of the Gulf for the year December 1948 to November 1949 , taken during the plankton survey, give a mean annual value of $17^{\circ} \mathrm{C}$. It is clear, therefore, that as suggested by Calman ${ }^{3}$, Penilia is not restricted by the $18^{\circ} \mathrm{C}$. mean annual isotherm in New Zealand. It is not known if Penilia extends south of the Hauraki Gulf.

From these observations, the temperature requirements for the establishment of Penilia in a district appear to be: (1) the mean annual surface temperature may be as low as $17^{\circ} \mathrm{C}$.; (2) a summer period is necessary in which the water remains at between $18^{\circ} \mathrm{C}$. and $20^{\circ} \mathrm{C}$. long enough for reproduction to occur.

Since neither of these conditions is found in the North Sea, it appears unlikely that Penilia will establish itself there, although it has been recorded", unless the North Sea offers unknown advantageous environmental conditions which will offset the lower temperatures.

Department of Zoology,

Auckland University College, New Zealand.

Dec. 16.

1 Krămer, A., Trans. N.Z. Inst., 27, 214 (1894).

${ }^{2}$ Report on Fisheries, Marine Department, N.Z. (1933-1941).

"Calman, W. T., Brit. Antarct. ("Terra Nova") Exp., 1910, Nat. Hist. Rep., Z̈. Brit. Antarct. 3, ("T 137 (1917).

${ }^{4}$ Cattley, J. G., and Harding, J. P., Nature, 164, 238 (1949).

\section{Occurrence of a Filter-feeding Mechanism in the Polychæte Nereis diversicolor}

THE Nereids as a group are regarded as typical examples of the predaceous errant polychretes ${ }^{1}$. Nereis diversicolor O. F. Müller (Annelida: Polychæta) has been recorded as feeding on small crabs, mussels, pieces of algæe, and also on detritus, and stress has always been laid on the role of the powerful jaws in seizing prey and dragging it down into the burrow $^{2}$. The discovery of a filter-feeding mechanism is therefore of interest.

Evidence points to the conclusion that the filterfeeding funnel is made from long fine threads secreted by the parapodial glands ${ }^{3,4}$ (Spinndrüsen ${ }^{3}$ ), and that these threads are moulded into the shape of a funnel by the parapodial setæ.

So far it has not been possible to determine the conditions under which Nereis diversicolor will use the filter-feeding mechanism; but the phenomenon has been observed many times in a number of different animals collected from two places. There can be no doubt that this mechanism is used, although its importance as a method of gathering food in the everyday life of the animal remains to be determined.

Worms were observed in pieces of glass tubing of suitable length and diameter immersed in a dish of sea water. When a suspension of carmine in sea water was added, the worm sometimes moved to one end of the tube and expanded laterally the anterior end of its body (from about the sixth to about the thirteenth parapodia-bearing segments), thus fixing the secretion of the parapodial glands to the wall of the tube. When the anterior end of the body relaxed 